\title{
Reactive oxygen species-Control and management using amphiphilic biosynthetic hydrogels for cardiac applications
}

\author{
Gnanaprakasam Thankam Finosh, Muthu Jayabalan* \\ Sree Chitra Tirunal Institute for Medical Sciences and Technology, Polymer Science Division, BMT Wing, Thiruvananthapuram, \\ India \\ Email: ${ }^{\text {muthujayabalan@,rediffmail.com }}$
}

Received 29 May 2013; revised 29 November 2013; accepted 15 December 2013

Copyright (C) 2013 Gnanaprakasam Thankam Finosh, Muthu Jayabalan. This is an open access article distributed under the Creative Commons Attribution License, which permits unrestricted use, distribution, and reproduction in any medium, provided the original work is properly cited.

\begin{abstract}
The reactive oxygen species (ROS) originated from endogenous and exogenous sources play a dominant role in the initiation and propagation of several diseases. It is therefore an urgent need to explore substances capable of encountering the ROS and resist the damage caused by ROS. The present paper deals with various aspects of generation and implications of ROS in the management of myocardial infarction. The use of biosynthetic amphiphilic biodegradable hydrogels in the control and management of ROS in myocardial infarction was studied using a biosynthetic hydrogel (PA-PEGDA) comprising poly(propylene fumarate)-co-alginate copolymer cross-linked with calcium and polyethylene glycol diacrylate (PEGDA). The effect of ROS on the cell growth was studied using $\mathrm{H}_{2} \mathrm{O}_{2}$ as model ROS molecule. The present hydrogel resists the penetration of ROS in the cell which was evident from the live/dead assay, increased intra cellular GSH levels when compared with the $\mathrm{H}_{2} \mathrm{O}_{2}$ treated positive and curcumin treated negative control cells. The Comet assay reveals genomic integrity of the cells exposed to the present hydrogel. The hydrogel is a promising injectable material for the management of myocardial infarction and ischemia.
\end{abstract}

Keywords: Biosynthetic Hydrogels; Alginate; Polypropylene Fumarate; Reactive Oxygen Species; Control and Management; Myocardial Applications

\section{INTRODUCTION}

The active role of various free radicals in the origin and propagation of several diseases and aging was already

"Corresponding author. revealed before five decades [1-5]. In biological systems oxygen free radicals or reactive oxygen species (ROS) and reactive nitrogen species (RNS) are significant since these can be formed as a result of normal cellular metabolism. These free radical species are able to execute both destructive and protective functions which depend on the concentration of these radicals present in the cells [6,7]. Apart from the cellular origin the free radicals, especially ROS can also be entered from the exogenous sources like cigarette smoke, radiations, environmental pollutants and medications. The reaction in the biological system that liberates energy is the oxidation of biomolecules that requires oxygen, which is the inevitable element to sustain life. So the chances of cellular ROS generation are very high when compared with that of RNS. Based on this, we are focusing more on the effects of ROS in this article.

Under normal physiological conditions, several types of ROS are formed inside the cells at very low concentrations which can be easily detoxified by normal cellular mechanisms. If the concentration of ROS is higher, they will escape from the cellular scavenging machineries and propagate by chain reaction leading to more than thousand fold increase in ROS concentration in the cells and leading to oxidative stress. In short, the oxidative stress is due to the imbalance between the free radical formation and their neutralization [8]. Since the ROS are highly unstable, the persistence of oxidative stress will increase the severity of cellular damage and these destructive effects will be described in the following sections. The common ROS and their half lives were displayed in the Table 1 and some of the indigenous and exogenous sources of ROS leading to oxidative stress are given in the Table 2.

The endogenous ROS generation occurs by enzymatic or non-enzymatic means. The former includes the biological processes like respiratory chain, phagocytosis 
Table 1. Representation and half life of some of the commonly ROS found in biological system.

\begin{tabular}{ccc}
\hline Free radical & Representation & Half-life (s) \\
\hline Superoxide & $\mathrm{O}^{\cdot-}$ & $10^{-6}$ \\
Hydroxyl radical & $\cdot \mathrm{OH}$ & $10^{-9}$ \\
Hydrogen peroxide & $\mathrm{H}_{2} \mathrm{O}_{2}$ & Stable \\
Peroxyl radical & $\mathrm{RCOO} \cdot$ & Seconds \\
Organic hydroperoxide & $\mathrm{RCOOH}$ & Stable \\
Singlet oxygen & ${ }^{1} \mathrm{O}_{2}$ & $10^{-6}$ \\
Ozone & $\mathrm{O}_{3}$ & Seconds \\
\hline
\end{tabular}

Table 2. Sources of free radicals that cause oxidative stress.

\begin{tabular}{|c|c|}
\hline Sources & Chemicals/processes \\
\hline Endogeneous & $\begin{array}{l}\text { Immune activation, inflammation, mental stress, intense } \\
\text { exercise, ischemia, cancer, aging }\end{array}$ \\
\hline Pollutants & $\begin{array}{l}\text { Vehicle exhaust, ozone, nitrogen dioxide, cigarette } \\
\text { smoke, heavy metals, pesticides, industrial exhaust, } \\
\text { smog }\end{array}$ \\
\hline Drugs & $\begin{array}{l}\text { Doxorubicin, bleomycin, vinblastin, cyclosporin, } \\
\text { tacrolimus, gentamycin }\end{array}$ \\
\hline Dietaries & Smocked meat, used oils, fat, alcohol \\
\hline Radiations & UV, X-rays, gamma-rays \\
\hline
\end{tabular}

prostaglandins synthesis and detoxification by cytochrome P450 system [9]. The superoxide is generated by the leakage of oxygen through Complexes I and III during the mitochondrial electron transport chain for the ATP synthesis [10]. The higher amount of superoxide causes the release of iron from iron containing molecules and the released iron then activates the Fenton reaction $\left(\mathrm{Fe}^{2+}+\right.$ $\left.\mathrm{H}_{2} \mathrm{O}_{2} \rightarrow \mathrm{Fe}^{3+}+\cdot \mathrm{OH}+\mathrm{OH}^{-}\right)$or Haber-Weiss $\left(\mathrm{O}^{--}+\mathrm{H}_{2} \mathrm{O}_{2}\right.$ $\rightarrow \mathrm{O}_{2}+\cdot \mathrm{OH}+\mathrm{OH}^{-}$) reaction leading to the formation of highly reactive $\bullet \mathrm{OH}[11,12]$. The simplest peroxyl radical hydroperoxyl radical (HOO), is the conjugated base of superoxide formed by the protonation of superoxide and these HOO radicals are notorious for initiating lipid peroxidation [13]. $\mathrm{H}_{2} \mathrm{O}_{2}$ is mainly produced in the peroxysomes, one of the organelles which utilize the major amount of oxygen, due to higher oxygen consumption and this $\mathrm{H}_{2} \mathrm{O}_{2}$ is then utilized to oxidize other biomolecules. In normal physiological conditions, the $\mathrm{H}_{2} \mathrm{O}_{2}$ in the peroxisomes were neutralized by catalase enzyme and maintained in minimal level. During abnormalities $\mathrm{H}_{2} \mathrm{O}_{2}$ is released to cytosol leading to oxidative stress [14]. $\mathrm{H}_{2} \mathrm{O}_{2}$ is also formed from superoxide by dismutation reaction by the enzyme superoxode dismutase (SOD) and also by D-amino acid oxidases, acetyl coenzyme A oxidase and uric acid oxidase [15]. The non enzymatic causes include the ionizing radiations can form most of the ROS by the photolysis of water in presence of oxygen [16].
The ROS at lower concentrations possess some physiological functions. The phagocytic cells utilize ROS (and also RNS) to oxidatievely destroy the invading foreign molecules or pathogens by a mechanism called respiratory burst [17]. ROS were reported to modulate some of the cellular activities like gene expression and growth regulation by reversible oxidation of nuclear factor-kappa B (NF- $\kappa$ B) and activator protein-1 (AP-1). The NF- $\kappa$ B mediated $T$ cell proliferation by ROS is essential for immune system. Mitogen activated protein kinase (MAPK) is a signaling molecule that is activated by ROS. The active role of ROS in developmental pathways as a second messenger is also proven. The involvement of ROS in biosynthesis of thyroid hormones and prostaglandins is also very crucial. ROS will also cause the apoptosis of transformed and virus infected cells through the mediation of tumor necrosis factor (TNF- $\alpha$ ) $[7,18]$. RNS is also having some biological functions like signaling, smooth muscle metabolism, leukocyte and platelet aggregation, neurotransmission, angiogenesis and so on [19].

Most biomolecules are susceptible for the attack by ROS that will deface their functions and ultimately lead to cell death. The cellular damage induced as a result of oxidative stress is illustrated in Figure 1. Membrane lipids [20-23], Nucleic acids [24,25], proteins [26-28] and sugars $[29,30]$ were also reported to be susceptible for ROS attack leading to cellular dysfunctions.

In order to get rid of the highly toxic effects of the ROS and their metabolites the nature itself has developed some protective measures which are executed either by direct or indirect means from exogenous or endogenous sources. The substances capable of encountering the ROS and resisting the damage caused by ROS can be collectively called antioxidants [31]. These antioxidants can be broadly divided into enzymatic and non enzymatic antioxidants. The major antioxidant enzymes and compounds that respond to ROS induced oxidative stress are given in the Table 3 and the action of cellular antioxidants is illustrated in Figure 2. The major antioxidant enzymes are Superoxide dismutases (SOD) (EC 1.15.1.1) [32,33], Catalase (EC 1.11.1.6) [34], Glutathione peroxidase (GPx) (EC 1.11.1.19) [35-37] Glutathione reductase (GR) [38] etc. Antioxidant biochemicals like Glutathione (GSH) also play a crucial role in scavenging the ROS due to its capability to readily donate protons to neutralize the ROS there by preventing the oxidative stress [39]. GSH is a low molecular weight peptide containing three amino acids $(\gamma$-glutamyl-cysteinyl-glycine). Their cellular concentration $(0.5-10 \mathrm{mM})$ is several folds greater than plasma concentration $(2-20 \mu \mathrm{M})$ [40]. The redox reactions of GSH and associated enzymes help the cells to resist much of the cellular ROS [41-44]. Many phytochemicals and several vitamins also have the antioxidant properties and all of these were reported to have the protective and 


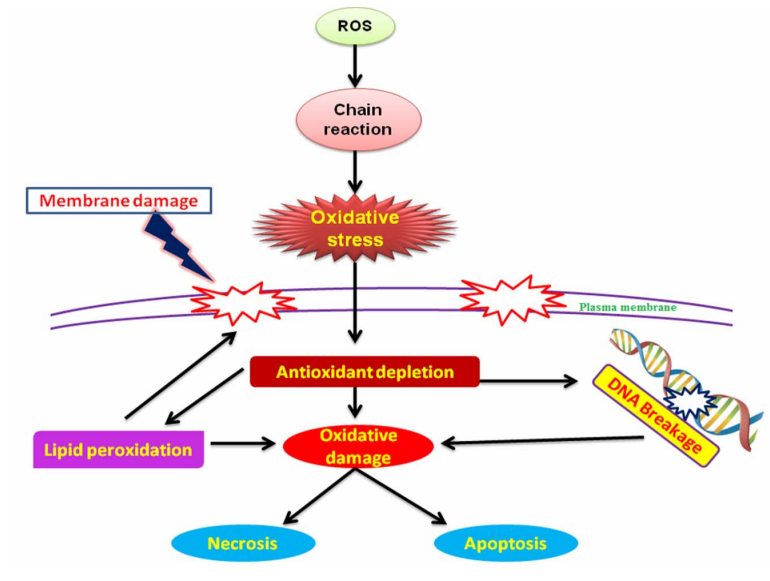

Figure 1. Cellular damage induced by oxidative stress.

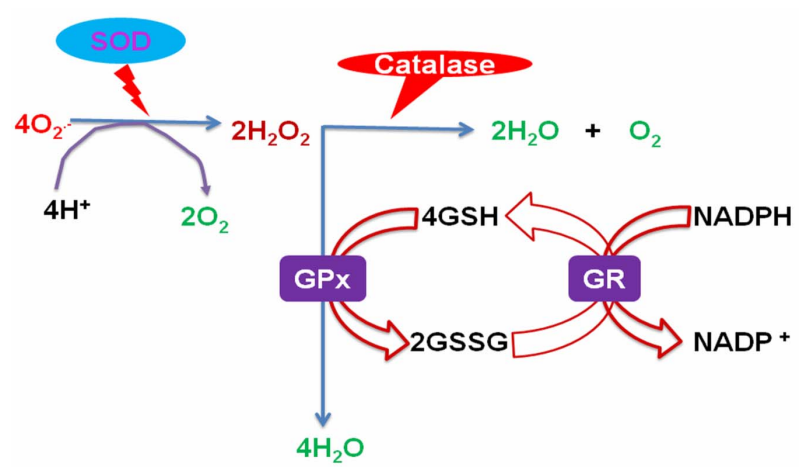

Figure 2. Cellular antioxidant defense system.

Table 3. The major antioxidant enzymes and compounds in the biological system.

\begin{tabular}{ccc}
\hline Antioxidant enzymes & Endogenous compounds & $\begin{array}{c}\text { Exogenous } \\
\text { compounds }\end{array}$ \\
\hline Superoxide dismutase (SOD) & Ascorbic acid & Polyphenols \\
Catalase (CAT) & Glutathione (GSH) & Caratenoids \\
Glutathione peroxidase (GPx) & Alpha-tocopherol & Flavanoids \\
Glutathione reductase (GR) & Uric acid & Curcuminoids \\
& & Alkaloids \\
\hline
\end{tabular}

disease preventing effects [45-54].

Acute myocardial infarction (AMI) is one of the most important health hazards throughout the world. AMI has devastating consequences in the early phase, such as cardiac rupture, and in the chronic phase, such as chronic heart failure, for which the risk is mainly determined by infarct size. Larger infarct size induces gross morphological, histological and molecular changes (cardiac remodelling) of cardiomyocytes and ECM of the infarcted as well as non infarcted regions which may further leads to cardiac arrhythmias, heart failure and mortality [55]. After the onset of the infarction an inherent repair program is initiated by the existing cardiac tissue. This in- cludes an initial inflammatory phase followed by initiation of angiogenesis and fibrotic changes in the myocardium. This healing process will take around two months leading to scar tissue formation [56]. Inflammatory responses and associated cytokine signaling along with free radical generation and granulocyte infiltration also lead to fibrotic scar formation. The scar tissue formation is a balance between the synthesis and degradation of the ECM protein collagen. Following an infarction collagen at the site starts to degrade by the proteolytic enzymes (matrix metalloproteinases or MMP) like collagenase (MMP-1) and gelatinase (MMP-2). The activity of MMPs will persist to cause the additional digestion of normal ECM leading to further loss of $\mathrm{CM}$ which will also result in reperfusion injury. The hyperactivity of MMPs is controlled by Tissue inhibitors of MMPs (TIMPs). TIMP activity increases to a maximum at $1^{\text {st }}$ week and persists for several other weeks and results in the accumulation of type I and III fibrillar collagens that will ultimately leads to scarring [57]. The disturbances in $\mathrm{Ca}^{2+}$ homeostasis are another complication that prolongs the disease.

The involvement of the oxidative stress in MI is clearly unveiled. The ROS generated after the reperfusion are mainly derived from mitochondria of reperfused myocardium and also from the inflammatory cells [58]. The ROS stimulate the production of inflammatory cytokines especially tumour necrosis factor- $\alpha$ (TNF- $\alpha$ ), IL- $1 \beta$, and IL-6 which in turn stimulate the production of more ROS [59]. The persistence of this will activate the MMPs and subsequent scar formation [60]. ROS can also impair the cardiac $\mathrm{Ca}^{2+}$ homeostasis and lead to $\mathrm{Ca}^{2+}$ overload and also result in extracellular $\mathrm{Ca}^{2+}$ influx due to peroxidation of the membrane lipids $[61,62]$. The neutrophills form the major source of ROS in the infarct area, still the endothelial cells and cardiomyocytes were also capable of generating ROS [63]. These ROS can lead either apoptotic or necrotic death to the cardiomyocytes and other cells of the cardiac tissue. The molecular events take place as a result of oxidative stress in the infarcted myocardium is displayed in Figure 3. The oxidative stress can mediate some signaling pathways in the myocardium which will regulate the expression of several genes for cardio protection [64-68].

The conventional medical management of MI include drugs like statins, beta-blockers, nitroglycerin and calcium antagonists, coronary artery bypass grafting $(\mathrm{CABG})$, implants like stents etc. Regenerative therapy and tissue engineering have emerged from the midst of these challenges and offered promising hope to millions of CVD patients throughout the sphere [69]. The antioxidant therapy was also found to be effective for the prevention of CVD [70-74]. Tissue engineering of heart forms one of the recent strategies for the treatment of the end stage cardiac complications. This approach will help to reduce 
the shortage of organ donors and immune rejection associated with the transplants and the implants [75]. The cardiac tissue engineering utilizes biodegradable scaffold materials either synthetic or biological or biosynthetic and the cells that constitute native cardiac tissue to reconstruct an in vitro cardiac tissue like construct, which can be implanted to repair and replace the lost myocardium [76, 77]. The various biomaterials used and the challenges for the in vitro construction of cardiac tissue were well reviewed by Wolfram-Hubertus Zimmermann et al. [78] and Brian Liau et al. [79].

Of several types of biomaterials used for cardiac tissue engineering, hydrogels from both natural and synthetic, origin gained much attention due to its inherent similarity with the native extra cellular matrix (ECM) (Table 4). Moreover the hydrogel biomaterials were proved to offer better cell attachment and response, biocompatibility, unique solute transport properties and so on which are very crucial for the construction of heart tissue in vitro [80]. The natural hydrogels were hailed for their biocompatibility and cell affinity but very weak in mechanical properties and exhibited uncontrolled degradation profile. Mechanical properties are very crucial for the engineering of tissues like heart since this organ is under high stress

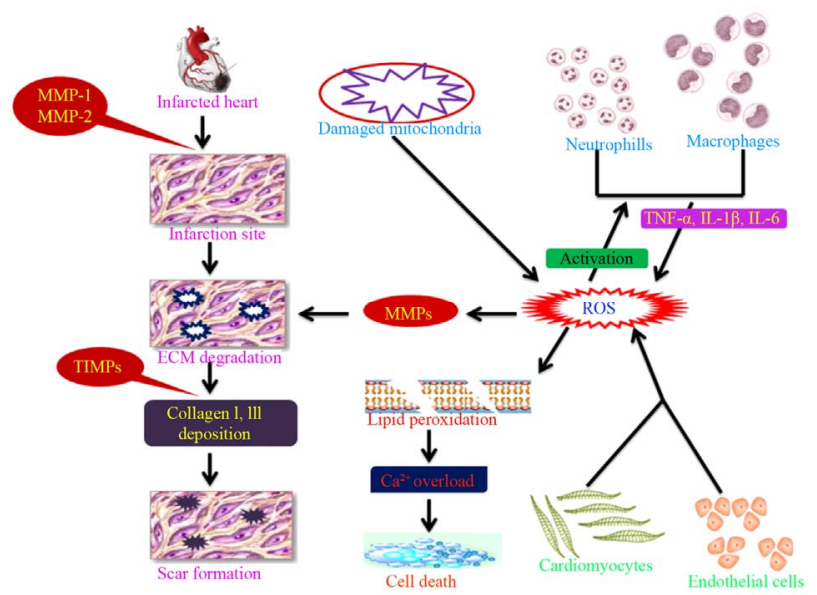

Figure 3. The effect of ROS in MI.

Table 4. Commonly used natural and synthetic hydrogels for cardiac tissue engineering applications.

\begin{tabular}{cc}
\hline Natural & Synthetic \\
\hline Alginate & Poly(Hydroxy ethyl methacrylate) \\
Collagen & Polyethylene glycol \\
Matrigel & Polyamides \\
Fibrin & Poly(N-isopropylacrylamide) \\
Hyaluronic acid & Poly(acrylic acid) \\
Gelatin & Polymethacrylamide \\
\hline
\end{tabular}

due to its pumping function. On the other hand the synthetic hydrogels are mechanically robust but their biocompatibility often offers challenge. Biosynthetic hydrogels formed from the combination of both natural and synthetic hydrogels can find advantages from both the partners [81].

There are reports showing that the biocompatibility of the synthetic hydrogels was improved by combining them with natural hydrogels like collagen, fibronectin or fibrin [82]. Zhang et al. reported PEGylated fibrin hydrogel enhanced the half-life of the encapsulated stromal derived factor (SDF) for cardiac tissue engineering applications [83]. Better cell adhesion was reported for the PEG-RGD hybrid hydrogels when compared with PEG hydrogels [84]. Poon et al., showed that the introduction of a MMP sensitive peptide to hyaluronic acid hydrogel improved the degradation profile [85]. There are several other combinations were also tried for tissue engineering applications which were proved to be physiochemically and biologically efficient [86].

The first process to take place immediately after implantation of a biomaterial is the interaction of biological fluid surrounding the implant site with the implanted material. This interaction will initiate the molecular events for the recruitment of inflammatory cells especially macrophages and neutrophills. The activation of macrophages will cause the increase in ROS concentration at the implant site [87]. Apart from angiogenesis the endothelial cells also mediate inflammation by the secretion of cytokines and adhesion molecules for leukocytes. The ROS from macrophages and neutrophills will be able to damage the endothelial cells and may lead to vascular dysfunction. The persistence of these ROS and associated oxidative stress in endothelial cells is one of the reasons for cardio vascular diseases. But the physiological concentration of ROS is necessary for wound healing by endothelial cells [88]. Shivaram et al. reported that the ROS level at the implant site is an indication of severe inflammation [89]. If the implanted biomaterials themselves have a potential to control the ROS in situ, it will be very advantageous for the success of the implants. But no such biomaterials with inherent ROS scavenging effects were reported elsewhere. Still some biomaterials especially hydrogels were explored for their ability to deliver antioxidant compounds so as to defend oxidative stress.

The effect of ROS in the initiation and progression of diseases like MI and their management strategies is briefly described in the above sections. Even though tissue engineering forms a promising and emerging treatment modality for cardiac complications we are lacking sufficient reports regarding the antioxidant effects of biomaterials. Cheng et al. used thermosensitive chitosan/ gelatin/glycerol phosphate hydrogel for the effective 
delivery of the natural antioxidant ferulic acid to prevent the ROS induced apoptosis in nucleus pulposus for the prevention of disc degeneration [90]. Lampe et al. proposed the antioxidant effect of lactic acid degraded from the co-polymer hydrogel composing poly(ethylene glycol) (PEG) and poly(lactic acid)-b-PEG-b-poly(lactic acid) dimethacrylate prepared for neurological application by monitoring the intra cellular GSH level [91]. Antioxidant polymers, poly(antioxidant $\beta$-amino ester), synthesized by incorporating polyphenolic antioxidants quercetin and curcumin was reported by Kimberly W. Anderson et al. showed better ROS scavenging activity and relieved oxidative stress to a greater extent. Qi et al. reported the antioxidant effects of the natural sulfated polysaccharide ulvan and its derivatives [92]. But more studies are needed for its use in biomedical applications at cellular and molecular level $[93,94]$. Chitosan is also reported to have antioxidant property which is attributed to its hydroxyl and amino groups that can react with free radicals [95]. According to Po-Jung Chien et al., the antioxidant activity of chitosan relates inversely with the molecular weight [95]. Still to the best of our knowledge no hydrogels with inherent antioxidant activity were reported for ROS scavenging effects for tissue engineering applications especially to that of heart.

We synthesized a biosynthetic co-polymer, poly(propylene fumarate)-co-alginate (PA), from the natural polysaccharide alginate and synthetic unsaturated polyester poly(propylene fumarate). The alginate portion of the PA was cross linked with $\mathrm{Ca}^{2+}$ and the double bonds with polyethylene glycol diacrylate (PEGDA) to form PAPEGDA hydrogel scaffold. The hydrogels were able to scavenge the in vitro generated ROS to a greater extent and supported healthy being of the cells even under oxidative stress signifying their potent application as cardiac tissue engineering scaffolds.

\section{MATERIALS AND METHODS}

\subsection{Preparation of Poly(propylene Fumarate)- Alginate-Polyethylene Glycol Diacrylate (PA-PEGDA) Hydrogel Scaffold}

A biosynthetic hydrogel scaffold PA-PEGDA was prepared using poly(propylene fumarate)-co-alginate (PA) and by crosslinking with calcium and polyethylene glycol diacrylate (PEGDA). Intially, poly(propylene fumarate) was prepared by reacting maleic anhydride and 1,2propylene glycol to form hydroxyl terminated poly propylene fumarate (HT-PPF) as reported elsewhere [96]. The HT-PPF was then co-polymerized with alginate in the ratio $1: 2$ under acidic conditions at $80^{\circ} \mathrm{C}$ to form PPFAlginate co-polymer (PA) which was dissolved in minimum distilled water. The alginate fraction of the copolymer was cross linked with $\mathrm{Ca}^{2+}$ and the PPF fraction with polyethylene glycol diacrylate (PEGDA) to form PA-PEGDA hydrogel scaffolds. The sheets of hydrogels so formed where washed thoroughly in distilled water, freeze dried, sterilized by ethylene oxide and stored aseptically for further studies. The structural representation of the details of the synthesis is given in Figure 4.

\subsection{Physical Characteristics of PA-PEGDA Hydrogel Scaffold}

The equilibrium water content (EWC) and swelling efficiency of PA-PEGDA hydrogel scaffolds were determined by immersing in distilled water. The hydrophilicity of the hydrogel was assessed by water contact angle determination by Wilhelmy method (KSV sigma 701 tensiometer). The healthy being of L929 cells in the hydrogel was determined by live/dead assay and direct contact assay. The details of these experiments were described in our previously published article [97].

\subsection{Cell Culture}

The mouse lung fibroblast cell line, L929 (NCCS, Pune) was grown in the medium composed of Dulbecco's Modified Eagle's Medium with glucose (Invitrogen), supplemented with $10 \%$ fetal bovine serum (FBS) and the antibiotics Pencillin, streptomycin and amphotericin-B at $37^{\circ} \mathrm{C}$ and $5 \% \mathrm{CO}_{2}$. The medium was replaced with fresh medium once in 3 days and the cells were subcultured after attaining around $70 \%$ confluence.

\subsection{Induction of Oxidative Stress to the Cell Culture}

L929 fibroblast cells were seeded in a 12 well plate and grown in DMEM to a subconfluent level. An oxidative stress was induced to culture of by the addition of $200 \mu \mathrm{M}$ $\mathrm{H}_{2} \mathrm{O}_{2}$ [98]. The protective effects of PA hydrogel scaffolds against ROS were determined by placing the hydrogel scaffolds of $1 \mathrm{~cm}$ diameter, prior swelled in culture medium on this oxidative stress induced cell layer and incubated at $37^{\circ} \mathrm{C}$ for $24 \mathrm{~h}$. After the incubation the protective effects of the PA-PEGDA hydrogels were determined by live dead assay, GSH staining and comet assay. A positive control of $50 \mu \mathrm{M}$ curcumin and two negative controls, $\mathrm{H}_{2} \mathrm{O}_{2}$ alone (without scaffolds) and cells alone (without scaffolds and $\mathrm{H}_{2} \mathrm{O}_{2}$ ), were also treated in the same manner.

\subsection{Determination of Apoptosis by Live/Dead Assay}

The live dead assay was conducted using of acridine orange $(100 \mu \mathrm{g} / \mathrm{ml})$ and ethidium bromide $(100 \mu \mathrm{g} / \mathrm{ml})$ cock tail and viewed immediately under an epifluore- 


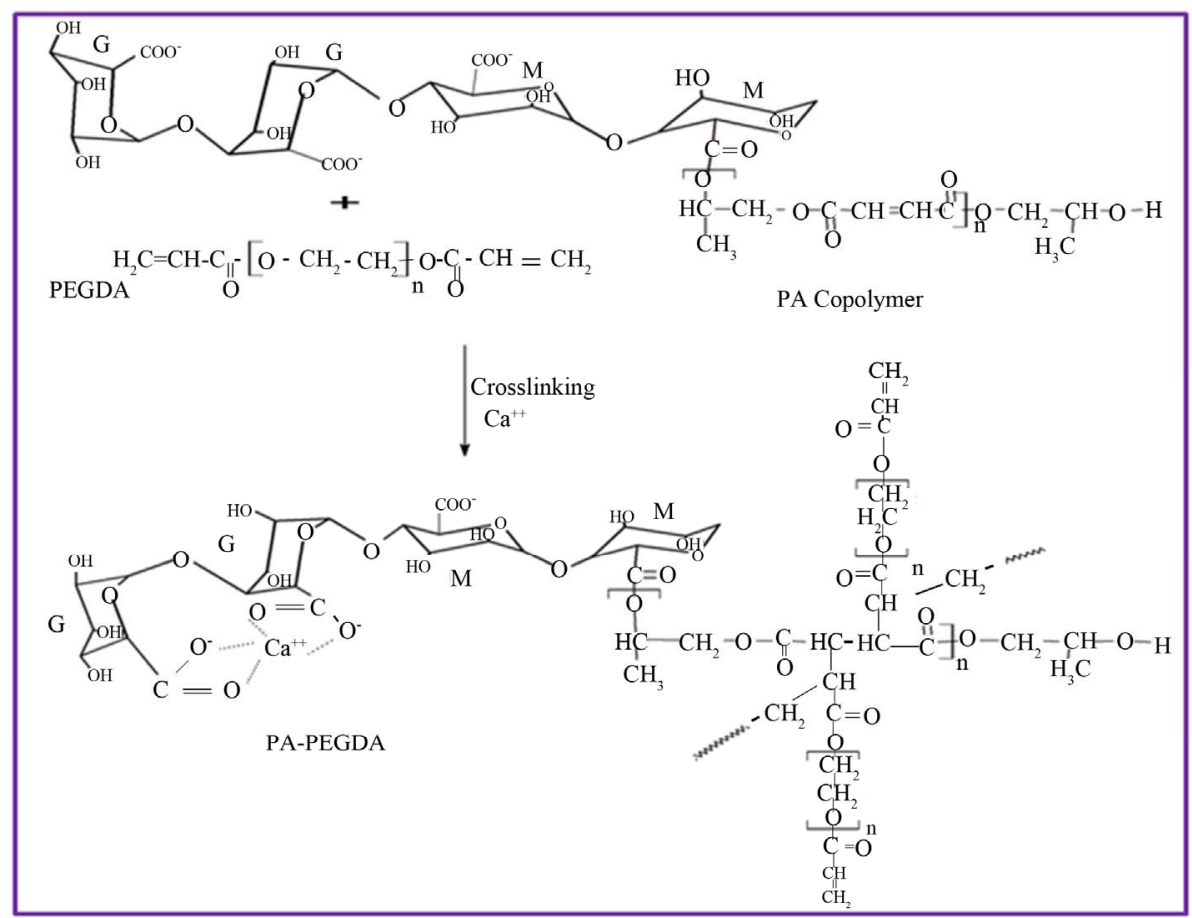

Figure 4. Preparation of PA-PEGDA hydrogel scaffolds.

scence microscope (Optika SRL) using blue filter for acridine orange and green filter for ethidium bromide as per our previously published protocol [97]. Two images taken from the same field without changing the settings of the microscope and were merged by Photoshop8 CS software.

\subsection{Intra Cellular GSH Staining}

The intra cellular GSH level was determined microscopically by Monochlorobimane (MCIB) after removing the scaffolds. The cells were washed with PBS and added 20 $\mu 1$ monochlorobimane $(10 \mu \mathrm{M}$ in methanol) and incubated at $37^{\circ} \mathrm{C}$ for $30 \mathrm{~min}$ and the unreacted dye was removed by PBS washing. The cells were then imaged by the fluorescent microscope at blue filter without changing the settings of the microscope. The images were then converted to 8bit gray scale and intensity of the images were quantified by the Imagej software and compared with that of controls [99] (Table 5).

\subsection{Evaluation of DNA Damage by Comet Assay}

Microscope slides were chilled at $4^{\circ} \mathrm{C}$ and coated with $0.75 \%$ normal melting point agarose (NMA) \& again cooled at $4^{\circ} \mathrm{C}$. This layer was removed before use $\&$ again coated with the same and covered with cover slips. Cell suspensions $\left(1 \times 10^{4} / 5-10 \mu \mathrm{l}\right)$ cultured on PA-PEGDA hydrogels extracts were mixed with $10 \mu \mathrm{l}$ of low melting point agarose \& pipetted over the first layer of NMA and cooled to set. NMA $(80 \mu \mathrm{l})$ was again used as a final protective layer. Then the cells were lysed in cold lysingsolution $(2.5 \mathrm{M} \mathrm{NaCl}, 100 \mathrm{mM} \mathrm{Na} 2 \mathrm{EDTA}, 10 \mathrm{mM}$ Tris $\mathrm{pH} 10 \& 1 \%$ SDS to which $10 \%$ DMSO \& $1 \%$ Triton $\times 100$ were added immediately prior to use for $1 \mathrm{hr}$. After lysis slides were placed in electrophoresis buffer $(300$ $\mathrm{mM} \mathrm{NaOH} \& \mathrm{Na}_{2}$ EDTA pH 13) for 20 to allow unwinding of DNA. Electrophoresis was conducted in the same buffer by applying an electric current of $0.8 \mathrm{~V} / \mathrm{cm}(300$ $\mathrm{mA}$ ) for $15 \mathrm{~min}$ using an electrophoresis supply. After electrophoresis the slides were washed in neutralization buffer $(0.4 \mu \mathrm{L}$ Tris, pH 7.5) \& stained with $50 \mu 1$ ethidium bromide $(20 \mu \mathrm{g} / \mathrm{ml})$ [100]. Images of the stained DNA were taken on the fluorescent microscope attached to a camera using green filter. The DNA damage was then quantified by using the comet scoring software TriTek CometScore Freeware 1.6.1.13 after analyzing around 50 cells from each sample.

\subsection{Statistical Analysis}

All experiments consisted of 5 or 6 samples from each group. The values are presented as means \pm standard deviations. Statistical analysis was done with one way ANOVA using online calculator, Statistics Calculator version- 3 beta and the level of significance was set at $p<$ 0.05 for all calculations.

\section{RESULTS AND DISCUSSION}

The hydrogel scaffold PA-PEGDA was prepared by the simultaneous co crosslinking of poly(propylene fumarate) 
alginate (PA) copolymer with PEGDA and calcium ions. The PA-PEGDA hydrogel possess appreciable water holding capacity onto its networks which is evident from the EWC $(61.12 \pm 1.79)$ and swelling $(157.48 \% \pm 11.94$ $\%)$. The contact angle studies reveal advancing (38.94 \pm $3.99)$ and receding $(40.89 \pm 4.69)$ water contact angle which delineates its amphiphilic character. The water content and amphiphilicity of this hydrogel promotes better viability of cells onto its interstices [97]. The noncytotoxic effects of the fibroblast cells upon contact with the hydrogels were confirmed by direct contact assay and live/dead assay (Figure 5).

The inherent ROS scavenging activity of PA-PEGDA hydrogel scaffolds were determined by live/dead assay, intra cellular GSH staining and by comet assay on oxidative stress induced L929 fibroblast cells. Live/dead assay was done by using ethidium bromide/acridine orange (EtBr/AO) staining (Figure 6). The merged images revealed that the toxicity was very minimal in the hydrogel treated samples when compared with that of curcumin treated (negative control) and control cells. The $\mathrm{H}_{2} \mathrm{O}_{2}$ treated controls displayed the apoptotic (orange cells) and necrotic cells (red cells) with a few numbers of healthy cells and all the cells were morphologically different from the normal (Figure 6(B)). The curcumin treatment recovered most of the cells and still some cells entered the early apoptotic phase which is shown by the yellow cells (Figure 6(C)). But in our hydrogel treated culture most cells (Figure 6(D)) were found to be healthy when compared with that of the control (Figure 6(A)).

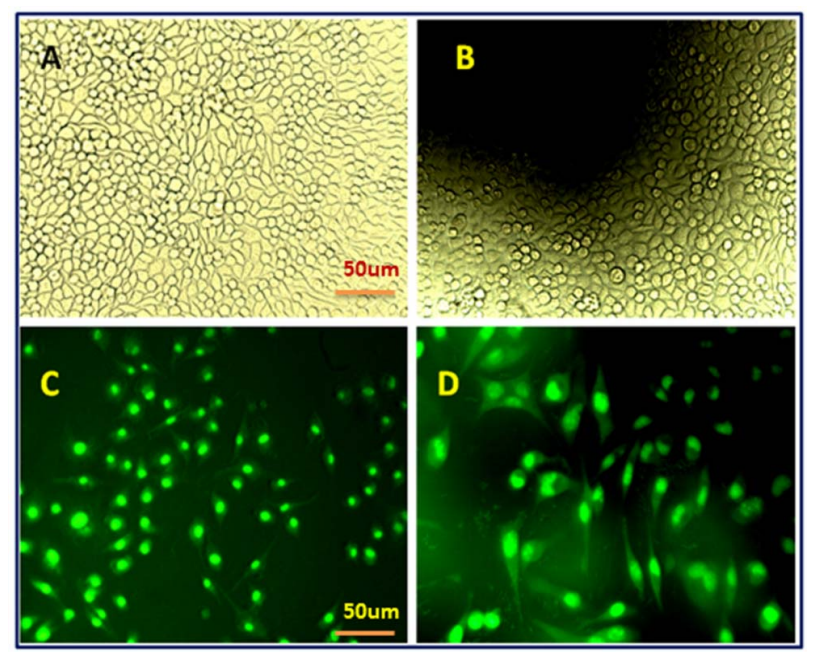

Figure 5. Direct contact assay (at $20 \times$ magnification) showed the hydrogels are nontoxic to the L929 cells upon contact with them (B) when compared with control cells seeded on polystyrene culture plates (A). Live/dead assay of L929 cells (at $20 \times$ magnification) using ethidium bromide/acridine orange displays green fluorescence indicating non apoptotic nature of cells grown on PA-PEGDA hydrogel (D) on comparison with control.
The mean gray value of the cells stained by Monochlorobimane for intra cellular GSH was determined by the imaging software imageJ. GSH staining (Figure 7) also showed a considerable decrease in the intensity in the cell culture treated with $\mathrm{H}_{2} \mathrm{O}_{2}$ showing the cellular utilization of GSH for the detoxification of ROS as detailed in the previous sections. The increased values in curcumin treated cells shows the scavenging effects of curcumin as reported elsewhere [101,102]. Interestingly the hydrogel treated cells displayed the values that are very close to the negative control and control cells. This shows the protecting effects of the hydrogel. But the exact mechanism needed to be studied in detail. Most probably it will be acting as a physical barrier to prevent the entry of ROS inside the cells. Moreover these ROS can also impart some cross links to the hydrogel network which will be able to neutralize these ROS.

The effects of ROS to the genetic material and their mechanism of action were also described in the previous sections. The DNA damage induced by the ROS was determined by single cell electrophoresis (Comet assay) (Figure 8). The Comet assay or single cell electrophoresis is a sensitive and rapid technique for quantifying and analyzing DNA damage in individual cells for the evaluation of genotoxicity. This assay can be used to detect DNA damage caused by double strand breaks, single strand breaks, alkali labile sites, oxidative base damage, and DNA cross-linking with DNA or protein. The Comet assay gain special significance in the field of biomaterials research due to the long latent period between exposure to genotoxic agent and genetic effect(s) becoming apparent. In the present investigation, the time $(24 \mathrm{~h})$ elapsed between exposures and measuring of the DNA damage is adequate for the repair of the possible lesions and enables to detect whether or not the chemical is able to produce the DNA damage.

The comets resulting from exposure to test hydrogel extract did not differ from that of the Control and negative control (curcumin treated cells). The relatively undamaged cell give comets consisting of a compact head without any prominent tail, indicating double-stranded intact DNA as observed with Control, negative control and test hydrogel. Comet originating from damaged cells observed with $\mathrm{H}_{2} \mathrm{O}_{2}$ treated sample (positive control) has a distinct head with a tail. The percentage of DNA in head on $\mathrm{H}_{2} \mathrm{O}_{2}$ treated cells showed the deleterious effects as shown in the Table 6. All these results can be correlated to the protective effects of the hydrogels against the free radicals and the ROS mediated complications on the MI were well delineated in the above sections. So the relevance of the PA-PEGDA hydrogels as scaffolds for cardiac tissue engineering applications can also be highlighted by their antioxidant effects. But the actual mechanism behind these effects remains unexplored. 
Table 5. GSH staining of PA-PEGDA hydrogel.

\begin{tabular}{cccc}
\hline SI/No & Samples $(\mathbf{n}=\mathbf{2 0})$ & Area $(\mathbf{s q . p x})(\mathbf{p}<\mathbf{0 . 0 0 0 1})$ & Mean gray Value $(\mathbf{p}<\mathbf{0 . 0 0 0 1})$ \\
\hline 1 & Control & $260.67 \pm 36.89$ & $27.42 \pm 5.6$ \\
2 & $\mathrm{H}_{2} \mathrm{O}_{2}$ & $309.9 \pm 30.37$ & $18.47 \pm 1.54$ \\
3 & Curcumin & $312.4 \pm 36.7$ & $24.01 \pm 1.34$ \\
4 & PA-PEGDA & $248.5 \pm 31.39$ & $27.6 \pm 2.0$ \\
\hline
\end{tabular}

Table 6. Comet assay of PA-PEGDA hydrogel.

\begin{tabular}{cccccc}
\hline Si/No & Samples $(\mathbf{n}=\mathbf{2 0})$ & Head Diameter $(\mathbf{p x})(\mathbf{p}<\mathbf{0 . 0 0 0 1})$ & \% DNA in Head $(\mathbf{p}<\mathbf{0 . 0 0 0 1})$ & \% DNA in Tail $(\mathbf{p}<\mathbf{0 . 0 1})$ Olive Moment $(\mathbf{p}<\mathbf{0 . 0 0 0 1})$ \\
\hline 1 & Control & $21.23 \pm 2.94$ & $99.16 \pm 0.77$ & $0.84 \pm 0.77$ & $0.02 \pm 0.03$ \\
2 & $\mathrm{H}_{2} \mathrm{O}_{2}$ & $25.05 \pm 4.63$ & $65.36 \pm 23.96$ & $18.48 \pm 32.21$ & $1.41 \pm 2.11$ \\
3 & Curcumin & $27.18 \pm 2.3$ & $99.45 \pm 0.87$ & $0.55 \pm 0.87$ & $0.03 \pm 0.06$ \\
4 & PA-PEGDA & $24.78 \pm 4.34$ & $99.16 \pm 0.93$ & $0.84 \pm 0.93$ & $0.07 \pm 0.09$ \\
\hline
\end{tabular}

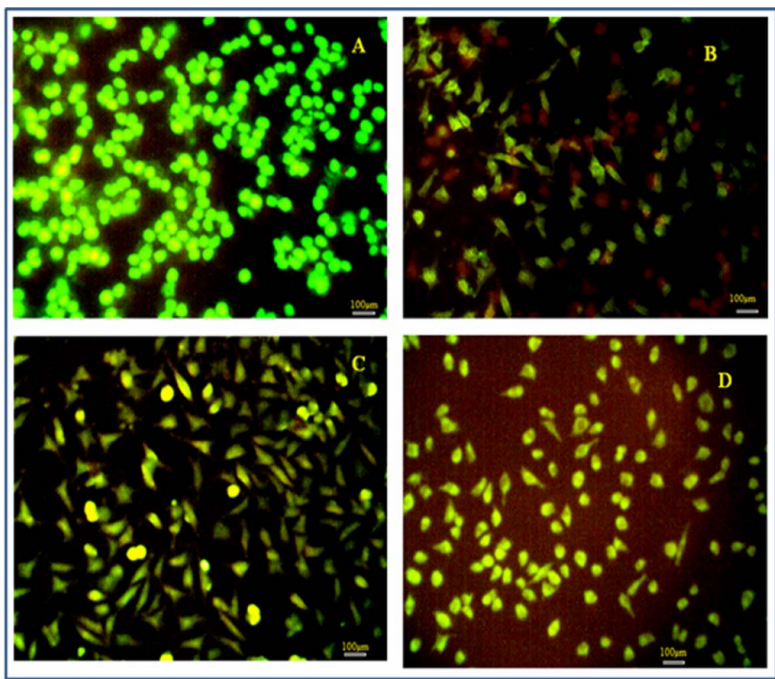

Figure 6. Image of L929 cells observed by live/dead assay. (4A) Control; (4B) $\mathrm{H}_{2} \mathrm{O}_{2}$ treated, (4C) Curcumin treated; and (4D) Hydrogel treated.

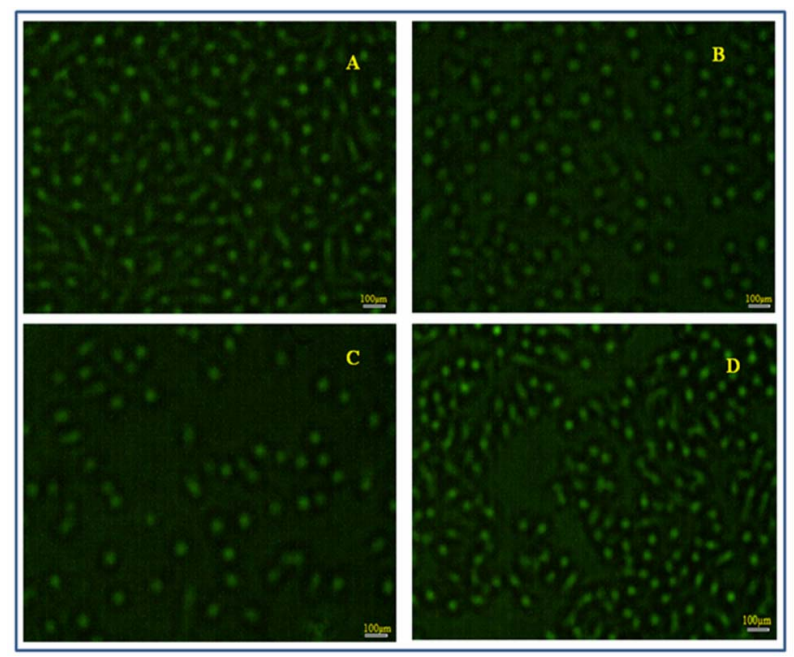

Figure 7. Images of cells after GSH staining. (5A) Control; (5B) $\mathrm{H}_{2} \mathrm{O}_{2}$ treated; (5C) Curcumin treated; and (5D) Hydrogel treated. From these, cells were selected for measuring mean gray value.

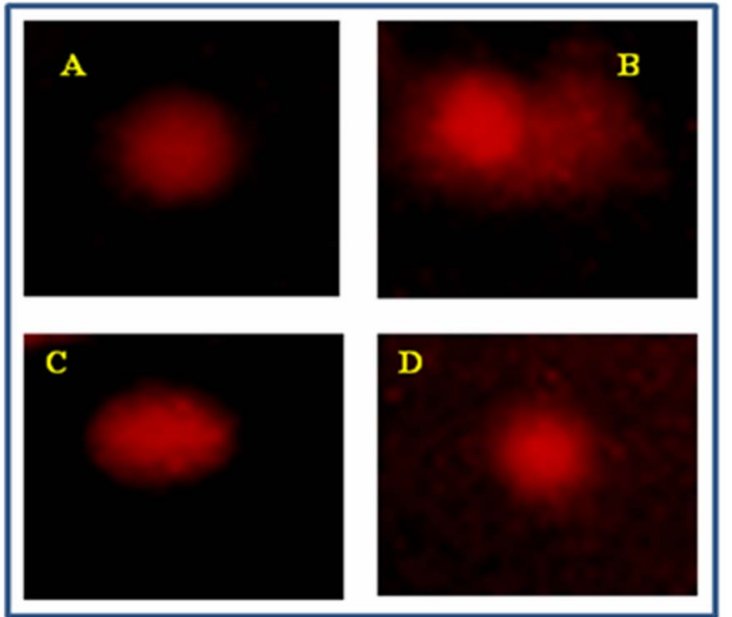

Figure 8. Image of nucleus of single cell observed by Comet assay. (6A) Control; (6B) $\mathrm{H}_{2} \mathrm{O}_{2}$ treated; (6C) Curcumin treated; and (4D) Hydrogel treated.

\section{CONCLUSION}

Even though several treatment methods are available for the management of MI, the encounter of ROS at the infarct site is still a challenge. Materials and methodologies to transform a passive biomaterial hydrogel scaffold into active barrier systems that may promote the survival of encapsulated cell from ROS and proactively protect encapsulated cells from immune-mediated damage are highly essential. The present hydrogel is more promising for the prevention of deleterious effect of ROS with inherent scavenging capability. The PA-PEGDA hydrogel resists the ROS penetration in the cell to a greater extent which was evident from the live/dead assay, increased intra cellular GSH level and genomic integrity. The present hydrogel is a potential candidate for long term cardiac tissue engineering applications.

\section{ACKNOWLEDGMENTS}

Thanks are due to Prof. K. Radhakrishnan, Director, SCTIMST for 
providing the facilities to carry out this work. G.T.F. acknowledges the financial support from Department of Science \&technology, New Delhi, Government of India and KSCST\&E, Kerala, India.

\section{REFERENCES}

[1] Gerschman, R., Gilbert, D.L., Nye, S.W., Dwyer, P. and Fenn, W.O. (1954) Oxygen poisoning and x-irradiationA mechanism in common. Science, 119, 623-626. http://dx.doi.org/10.1126/science.119.3097.623

[2] Harman, D. (1956) Aging - A theory based on free-radical and radiation-chemistry. Journals of Gerontology, 11, 298-300. http://dx.doi.org/10.1093/geronj/11.3.298

[3] Gilbert, D.L. (2000) Fifty years of radical ideas. Annals of the New York Academy of Sciences, 899, 1-14. http://dx.doi.org/10.1111/j.1749-6632.2000.tb06172.x

[4] Evans, P. and Halliwll, B. (2001) Micronutrients: Oxidant/antioxidant status. British Journal of Nutrition, 85, 67-74. http://dx.doi.org/10.1079/BJN2000296

[5] Halliwell, B. (1994) Free radicals, antioxidants, and human disease: Curiosity, cause, or consequence? Lancet, 344, 721-724. http://dx.doi.org/10.1016/S0140-6736(94)92211-X

[6] Valko, M., Rhodes, C.J., Moncol, J., Izakovic, M. and Mazur, M. (2006) Free radicals, metals and antioxidants in oxidative stress-induced cancer. Chemico-Biological Interactions, 160, 1-40. http://dx.doi.org/10.1016/j.cbi.2005.12.009

[7] Droge, W. (2002) Free radicals in the physiological control of cell function. Physiological Reviews, 82, 47-95.

[8] Young, I. and Woodside, J. (2001) Antioxidants in health and disease. Journal of Clinical Patholology, 54, 176186. http://dx.doi.org/10.1136/jep.54.3.176

[9] Willcox, J.K., Ash, S.L. and Catignani, G.L. (2004) Antioxidants and prevention of chronic disease. Review. Critical Reviews in Food Science and Nutrition, 44, 275295. http://dx.doi.org/10.1080/10408690490468489

[10] Muller, F.L., Liu, Y. and Van Remmen, H. (2004) Complex III releases superoxide to both sides of the inner mitochondrial membrane. The Journal of Biological Chemistry, 279, 49064-49073.

http://dx.doi.org/10.1074/jbc.M407715200

[11] Leonard, S.S., Harris, G.K. and Shi, X. (2004) Metalinduced oxidative stress and signal transduction. Free Radical Biology and Medicine, 37, 1921-1942. http://dx.doi.org/10.1016/j.freeradbiomed.2004.09.010

[12] Liochev, S.I. and Fridovich, I. (2002) The Haber-Weiss cycle - 70 years later: An alternative view. Redox Report, 7, 55-57. http://dx.doi.org/10.1016/j.freeradbiomed.2004.09.010

[13] Aikens, J. and Dix, T.A. (1991) Perhydroxyl radical (HOO•) initiated lipid-peroxidation - The role of fattyacid hydroperoxides. The Journal of Biological Chemistry, 266, 15091-15098.

[14] Valko, M., Izakovic, M., Mazur, M., Rhodes, C.J. and Telser, J. (2004) Role of oxygen radicals in DNA damage and cancer incidence. Molecular and Cellular Biology,
266, 37-56.

[15] Fang, Y.Z. (1991) Effect of ionizing radiation on superoxide dismutase in vitro and in vivo. In: Fang, Y.Z., Ed., Advances in Free Radical Biology and Medicine, Atomic Energy Press, Beijing, 1.

[16] Fang, Y.Z. (2002) Free radicals and nutrition. In: Fang, Y.Z. and Zheng, R.L., Eds., Theory and Application of Free Radical Biology, Scientific Press, Beijing, 647.

[17] DeCoursey, T.E. and Liget, I.E. (2005) Regulation and termination of NADPH oxidase activity. Cellular and Molecular Life Sciences, 62, 2173-2193. http://dx.doi.org/10.1007/s00018-005-5177-1

[18] Schrec, R. and Baeuerle, P.A. (1991) A role for oxygen radicals as second messengers. Trends in Cell Biology, 1, 39-42. http://dx.doi.org/10.1016/0962-8924(91)90072-H

[19] Ignarro, L.J., Cirino, G., Casini, A. and Napoli, C. (1999) Nitric oxide as a signaling molecule in the vascular system: an overview. Journal of Cardiovascular Pharmacology, 34, 879-886. http://dx.doi.org/10.1097/00005344-199912000-00016

[20] Etsuo, N., Yasukazu, Y., Yoshiro, S. and Noriko, N. (2005) Lipid peroxidation: Mechanisms, inhibition, and biological effects. Biochemical and Biophysical Research Communications, 338, 668-676. http://dx.doi.org/10.1016/j.bbrc.2005.08.072

[21] Fedtke, N., Boucheron, J.A., Walker, V.E. and Swenberg, J.A. (1990) Vinyl chloride-induced DNA adducts. 2. Formation and persistence of 7-2'-oxoethylguanine and n2,3ethenoguanine in rat-tissue DNA. Carcinogenesis, 11, 1287-1292. http://dx.doi.org/10.1093/carcin/11.8.1287

[22] Fink, S.P., Reddy, G.R. and Marnett, L.J. (1997) Mutagenicity in Escherichia coli of the major DNA adduct derived from the endogenous mutagen malondialdehyde. Proceedings of the National Academy of Sciences, 94, 8652-8657. http://dx.doi.org/10.1073/pnas.94.16.8652

[23] Beckman, K.B. and Ames, B.N. (1997) Oxidative decay of DNA. The Journal of Biological Chemistry, 272, 19633-19636. http://dx.doi.org/10.1074/jbc.272.32.19633

[24] Thomas, B.K., Anastassiya, B.G., Polycarpos, P. and Alexandros, G.G. (2011) Role of oxidative stress and DNA damage in human carcinogenesis. Mutation Research, 711, 193-201. http://dx.doi.org/10.1016/j.mrfmmm.2010.12.016

[25] Konsta, A.A., Visvardis, E.E., Haveles, K.S., Georgakilas, A.G. and Sideris, E.G. (2003) Detecting radiationinduced DNA damage: From changes in dielectric properties to programmed cell death. Journal of Non-Crystalline Solids, 305, 295-302. http://dx.doi.org/10.1016/S0022-3093(02)01102-X

[26] Stadtman, E.R. (2004) Role of oxidant species in aging. Current Medicinal Chemistry, 11, 1105-1112. http://dx.doi.org/10.2174/0929867043365341

[27] Dalle-Donne, I., Rossi, R., Colombo, R., Giustarini, D. and Milzani, A. (2006) Biomarkers of oxidative damage in human disease. Clinical Chemistry, 52, 601-623. http://dx.doi.org/10.1373/clinchem.2005.061408

[28] Ling, J. and Söll, D. (2010) Severe oxidative stress induces protein mistranslation through impairment of an 
aminoacyl-tRNA synthetase editing site. Proceedings of the National Academy of Sciences, 107, 4028-4033. http://dx.doi.org/10.1073/pnas.1000315107

[29] Garrison, W.M. (1987) Reaction mechanisms in the radiolysis of peptides, polypeptides, and proteins. Chemical Reviews, 87, 381-398.

http://dx.doi.org/10.1021/cr00078a006

[30] Bonnefont-Rousselot, D. (2002) Glucose and reactive oxygen species. Current Opinion in Clinical Nutrition and Metabolic Care, 5, 561-568. http://dx.doi.org/10.1097/00075197-200209000-00016

[31] Kohe, R. (1999) Skin antioxidants: Their role in aging and in oxidative stress - New approaches for their evaluation. Biomedicine \& Pharmacotherapy, 53, 181-192. http://dx.doi.org/10.1016/S0753-3322(99)80087-0

[32] Hassan, H.M. (1989) Microbial superoxide dismutases. Advances in Genetics, 26, 65-97. http://dx.doi.org/10.1016/S0065-2660(08)60223-0

[33] Steinman, H.M. (1986) Bacteriocuprein superoxide dismutase of Photobacterium leiognathi. Isolation and sequence of the gene and evidence for a precursor form. The Journal of Biological Chemistry, 262, 1882-1887.

[34] Aebi, H.E. (1987) Enzymes 1: Oxidoreductases, transferases. In: Bergmeyer, H., Ed., Methods of Enzymatic Analysis, Verlag Chemie, Weinheim, 273-282.

[35] Tappel, A.L. (1978) Glutathione peroxidase and hydroperoxides. Methods in Enzymology, 52, 506-513. http://dx.doi.org/10.1016/S0076-6879(78)52055-7

[36] Imai, H., Narashim, K., Arai, M., Sakamoto, H., Chiba, N. and Nakagawa, Y. (1998) Suppression of leukotriene formation in RBL-2H3 cells that overexpressed phospholipid hydroperoxide glutathione peroxidase. Journal of Biological Chemistry, 273, 1990-1997. http://dx.doi.org/10.1074/jbc.273.4.1990

[37] De Haan, J.D., Bladier, C., Griffiths, P., Michael, K., Ross, D.O., Nam, S.C., Bronson, R.T., Mary, J., Steven, W., Shao, S.Z., Philip, M.B., Paul, J.H. and Ismail, K. (1998) Mice with a homozygous null mutation for the most abundant glutathione peroxidase, Gpx1, show increased susceptibility to the oxidative stress-inducing agents paraquat and hydrogen peroxide. Journal of Biological Chemistry, 273, 22528-22536. http://dx.doi.org/10.1074/jbc.273.35.22528

[38] Kim, S.J., Jung, H.J., Hyun, D.H., Park, E.H., Kim, Y.M. and Lim, C.J. (2010) Glutathione reductase plays an antiapoptotic role against oxidative stress in human hepatoma cells. Biochimie, 92, 927-932. http://dx.doi.org/10.1016/j.biochi.2010.03.007

[39] Clark, S.F. (2002) The biochemistry of antioxidants revisited. Nutrition in Clinical Practice, 17, 5-17. http://dx.doi.org/10.1177/011542650201700105

[40] Wu, J.M. and Hsieh, T.C. (2011) Resveratrol: A cardioprotective substance. Annals of the New York Academy of Sciences, 1215, 16-21.

[41] Lu, S.C. (2001) Regulation of glutathione synthesis. Current Topics in Cellular Regulation, 36, 95-116. http://dx.doi.org/10.1016/S0070-2137(01)80004-2

[42] Meister, A. (1991) Glutathione deficiency produced by inhibition of its synthesis, and its reversal; applications in research and therapy. Pharmacology \& Therapeutics, 51, 155-194.

http://dx.doi.org/10.1016/0163-7258(91)90076-X

[43] Griffith, O.W. (1999) Biologic and pharmacologic regulation of mammalian glutathione synthesis. Free Radical Biology and Medicine, 27, 922-935.

http://dx.doi.org/10.1016/S0891-5849(99)00176-8

[44] Fujii, T., Endo, T., Fujii, J. and Taniguchi, N. (2002) Differential expression of glutathione reductase and cytosolic glutathione peroxidase, GPX1, in developing rat lungs and kidneys. Free Radical Research, 36, 1041-1049. http://dx.doi.org/10.1080/1071576021000006725

[45] Liu, R.H. (2003) Health benefits of fruits and vegetables are from additive and synergistic combination of phytochemicals. The American Journal of Clinical Nutrition, $\mathbf{7 8}$, 5175-5205.

[46] Schulz, T.J., Zarse, K., Voigt, A., Urban, N., Birringer, M. and Ristow, M. (2007) Glucose restriction extends caenorhabditis elegans life span by inducing mitochondrial respiration and increasing oxidative stress. Cell Metabolism, 6, 280-293. http://dx.doi.org/10.1016/j.cmet.2007.08.011

[47] Cherubini, A., Vigna, G.B., Zuliani, G., Ruggiero, C., Senin, U. and Fellin, R. (2005) Role of antioxidants in atherosclerosis: epidemiological and clinical update. Current Pharmaceutical Design, 11, 2017-2032. http://dx.doi.org/10.2174/1381612054065783

[48] Stanner, S.A., Hughes, J., Kelly, C.N.M. and Buttriss, J. (2004) A review of the epidemiological evidence for the 'antioxidant hypothesis'. Public Health Nutrition, 7, $407-$ 422. http://dx.doi.org/10.1079/PHN2003543

[49] Sun, J., Chu, Y-F., Wu, X. and Liu, R.H. (2002) Antioxidant and antiproliferative activities of fruits. Journal of Agricultural and Food Chemistry, 50, 7449-7454. http://dx.doi.org/10.1021/jf0207530

[50] Ronald, L.P. and Guohua, C. (2000) Antioxidant phytochemicals in fruits and vegetables: Diet and health implications. Hortscience, 35, 588-593.

[51] Katsunari, A.K., Ito, I. and Higashio, J.T. (1999) Evaluation of antioxidative activity of vegetable extracts in linoleic acid emulsion and phospholipid bilayers. Journal of Science of Food and Agriculture, 79, 2010-2016.

[52] Flohé, R.B., Frank, J., Salonearn, J.T., Neuzil, J., Zingg, J. and Azzi, A. (2002) The European perspective on vitamin E current knowledge and future research. American Journal of Clinical Nutrition, 76, 703-716.

[53] Duduku, K., Rosalam, S. and Awang, B. (2007) Phytochemical antioxidants for health and medicine-A move towards nature. Biotechnology and Molecular Biology Reviews, 1, 97-104.

[54] Vega-Lopez, S., Devaraj, S. and Jialal, I. (2004) Oxidative stress and antioxidant supplementation in the management of diabetic cardiovascular disease. Journal of Investigative Medicine, 52, 24-32. http://dx.doi.org/10.2310/6650.2004.11932

[55] White, H.D., Norris, R.M., Brown, M.A., Brandt, P.W., Whitlock, R.M. and Wild, C.J. (1987) Left ventricular end-systolic volume as the major determinant of survival after recovery from myocardial infarction. Circulation, 


\section{6, 44-51. http://dx.doi.org/10.1161/01.CIR.76.1.44}

[56] Jugdutt, B.I. and Amy, W.M. (1986) Healing after myocardial infarction in the dog: Changes in infarct hydroxyproline and topography. Journal of the American College of Cardiology, 7, 91-102. http://dx.doi.org/10.1016/S0735-1097(86)80265-0

[57] Jack, M.C., Jagannadha, C.K., Eduardo, G., Ramareddy, V.G. and Karl, T.W. (1995) The rat myocardium after infarction. Journal of Molecular and Cellular Cardiology, 27, 1281-1292.

[58] Waypa, G.B., Marks, J.D., Mack, M.M., Boriboun, C., Mungai, P.T. and Schumacker, P.T. (2002) Mitochondrial reactive oxygen species trigger calcium increases during hypoxia in pulmonary arterial myocytes. Circulation Research, 91, 719-726.

http://dx.doi.org/10.1161/01.RES.0000036751.04896.F1

[59] Nakamura, K., Fushimi, K., Kouchi, H., Mihara, K., Miyazaki, M., Ohe, T. and Namba, M. (1998) Inhibitory effects of antioxidants on neonatal rat cardiac myocyte hypertrophy induced by tumor necrosis factor- $\alpha$ and angiotensin II. Circulation, 98, 794-799. http://dx.doi.org/10.1161/01.CIR.98.8.794

[60] Rohde, L.E., Ducharme, A., Arroyo, L.H., Aikawa, M., Sukhova, G.H., Lopez-Anaya, A., McClure, K.F., Mitchell, P.G., Libby, P. and Lee, R.T. (1999) Matrix metalloproteinase inhibition attenuates early left ventricular enlargement after experimental myocardial infarction in mice. Circulation, 99, 3063-3070. http://dx.doi.org/10.1161/01.CIR.99.23.3063

[61] Rothstein, E.C., Byron, K.L., Reed, R.E., Fliegel, L. and Lucchesi, P.A. (2002) $\mathrm{H}_{2} \mathrm{O}_{2}$-Induced $\mathrm{Ca}^{2+}$ overload in NRVM involves ERK1/2 MAP kinases: Role for an NHE1-dependent pathway. American Journal of PhysiologyHeartand CirculatoryPhysiology, 283, 598-605.

[62] Mukherjee, S.B., Das, M., Sudhandiran, G. and Shaha, C. (2002) Increase in cytosolic $\mathrm{Ca}^{2+}$ levels through the activation of non-selective cation channels induced by oxidative stress causes mitochondrial depolarization leading to apoptosis-like death in Leishmania donovani promastigotes. Journal of Biological Chemistry, 277, 24717-24727. http://dx.doi.org/10.1074/jbc.M201961200

[63] Duilio, C., Ambrosio, G., Kuppusamy, P., DiPaula, A., Becker, L.C. and Zweier, J.L. (2001) Neutrophils are primary source of $\mathrm{O}_{2}$ radicals during reperfusion after prolonged myocardial ischemia. American Journal of Physiology-Heartand Circulatory Physiology, 280, 2649-2657.

[64] Sanjuan-Pla, A., Cervera, A.M., Apostolova, N., Garcia-Bou, R., Victor, V.M., Murphy, M.P. and McCreath, K.J. (2005) A targeted antioxidant reveals the importance of mitochondrial reactive oxygen species in the hypoxic signaling of HIF-1 $\alpha$. FEBS Letters, 79, 2669-2674. http://dx.doi.org/10.1016/j.febslet.2005.03.088

[65] Philipp, S., Critz, S.D., Cui, L., Solodushko, V., Cohen, M.V. and Downey, J.M. (2006) Localizing extracellular signal-regulated kinase (ERK) in pharmacological preconditioning's trigger pathway. Basic Research in Cardiology, 101, 159-167. http://dx.doi.org/10.1007/s00395-005-0566-Z

[66] Alcendor, R.R., Gao, S., Zhai, P., Zablocki, D., Holle, E.,
Yu, X.Z., Tian, B., Wagner, T., Vatner, S.F. and Sadoshima, J. (2007) Sirt1 regulates aging and resistance to oxidative stress in the heart. Circulation Research, 100, 1512-1521.

http://dx.doi.org/10.1161/01.RES.0000267723.65696.4a

[67] Afanas'ev, I. (2010) Reactive oxygen species and age-related genes p66shc, Sirtuin, Fox03 and Klotho in senecence. Oxidative Medicine and Cellular Longevity, 3, 77-85. http://dx.doi.org/10.4161/oxim.3.2.11050

[68] Sundaresan, N.R., Gupta, M., Kim, G., Rajamohan, S.B., Isbatan, A. and Gupta, M.P. (2009) Sirt3 blocks the cardiac hypertrophic response by augmenting Foxo3a-dependent antioxidant defense mechanisms in mice. Journal of Clinical Investigation, 119, 2758-2771.

[69] Finosh, G.T. and Jayabalan, M. (2012) Regenerative therapy and tissue engineering for the treatment of end-stage cardiac failure-New developments and challenges. Biomatter, 2, 1-14. http://dx.doi.org/10.4161/biom.19429

[70] Wu, G., Fang, Y., Yang, S., Lupton, J.R. and Turner, N.D. (2004) Glutathione metabolism and its implications for health. Journal of Nutrition, 134, 489-492.

[71] Asiri, Y.A. (2010) Probucol attenuates cyclophosphamide-induced oxidative apoptosis, p53 and Bax signal expression in rat cardiac tissues. Oxidative Medicine and Cellular Longevity, 3, 308-316.

[72] Tripathi, P., Chandra, M. and Misra, M.K. (2009) Oral administration of 1-arginine in patients with angina or following myocardial infarction may be protective by increasing plasma superoxide dismutase and total thiols with reduction in serum cholesterol and xanthine oxidase. Oxidative Medicine and Cellular Longevity, 2, 231-237. http://dx.doi.org/10.4161/oxim.2.4.9233

[73] Chen, J., Shearer, G.C., Chen, Q., et al. (2011) Omega-3 fatty acids prevent pressure overload-induced cardiac fibrosis through activation of cyclic GMP/protein kinase $\mathrm{g}$ signaling in cardiac fibroblasts. Circulation, 123, 584-593. http://dx.doi.org/10.1161/CIRCULATIONAHA.110.9718 $\underline{53}$

[74] Das, A., Salloum, F.N., Xi, L., Rao, Y.J. and Kukreja, R.C. (2009) ERK phosphorylation mediates sildenafil-induced myocardial protection against ischemia-reperfusion injury in mice. American Journal of Physiology, 296, 1236-1243.

[75] Boyle, A. (2009) Current status of cardiac transplantation and mechanical circulatory support. Current Heart Failure Reports, 6, 28-33. http://dx.doi.org/10.1007/s11897-009-0006-8

[76] Kofidis, T., Akhyari, P., Boublik, J., Theodorou, P., Martin, U., Ruhparwar, A., Fischer, S., Eschenhagen, T., Kubis, H.P., Kraft, T., Leyh, R. and Haverich, A. (2002) In Vitro engineering of heart muscleartificial myocardial tissue. Journal of Thoracic and Cardiovascular Surgery, 124, 63-69. http://dx.doi.org/10.1067/mtc.2002.121971

[77] van Luyn, M.J., Tio, R.A., van Seijen, X.J., Plantinga, J.A., de Leij, L.F., DeJongste, M.J. and van Wachem, P.B. (2002) Cardiac tissue engineering: Characteristics of in unison contracting two- and three-dimensional neonatal rat ventricle cell (co)-cultures. Biomaterials, 23, 47934801. http://dx.doi.org/10.1016/S0142-9612(02)00230-2

[78] Wolfram-Hubertus, Z., Ivan, M., Thomas, E. (2004) En- 
gineered heart tissue for regeneration of diseased hearts. Biomaterials, 25, 1639-1647. http://dx.doi.org/10.1016/S0142-9612(03)00521-0

[79] Liau, B., Zhang, D.H. and Bursac, N. (2012) Functional cardiac tissue engineering. Regenerative Medicine, 7, 187206. http://dx.doi.org/10.2217/rme.11.122

[80] Brandon, V.S., Shahana, S.K., Omar, Z.F., Ali, K., Nicholas, A.P. (2009) Hydrogels in regenerative medicine. $A d-$ vanced Materials, 21, 3307-3329. http://dx.doi.org/10.1002/adma.200802106

[81] Li, Z.Q. and G, J.J. (2011) Hydrogels for cardiac tissue engineering. Polymers, 3, 740-761. http://dx.doi.org/10.3390/polym3020740

[82] Kim, P.D., Peyton, S.R., Van, A.J. and Putnam, A.J. (2009) The influence of ascorbic acid, TGF-beta1, and cell-mediated remodeling on the bulk mechanical properties of 3-D PEG-fibrinogen constructs. Biomaterials, 30, 38543864.

http://dx.doi.org/10.1016/j.biomaterials.2009.04.013

[83] Zhang, G., Nakamura, Y., Wang, X., Hu, Q., Suggs, L.J. and Zhang, J. (2007) Controlled release of stromal cellderived factor-1 alpha in Situ increases c-kit ${ }^{+}$cell homing to the infarcted heart. Tissue Engineering, 13, 2063-2071. http://dx.doi.org/10.1089/ten.2006.0013

[84] Miller, J.S., Shen, C.J., Legant, W.R., Baranski, J.D., Blakely, B.L. and Chen, C.S. (2010) Bioactive hydrogels made from step-growth derived PEG-peptide macromers. Biomaterials, 31, 3736-3743. http://dx.doi.org/10.1016/j.biomaterials.2010.01.058

[85] Poon, Y.F., Cao, Y., Zhu, Y., Judeh, Z.M.A. and ChanPark, M.B. (2009) Addition of beta-malic acidcontaining poly(ethylene glycol) dimethacrylate to form biodegradeable and biocompatible hydrogels. Biomacromolecules, 10, 2043-2052. http://dx.doi.org/10.1021/bm801367n

[86] Lee, W.F. and Chen, Y.J. (2001) Studies on Preparation and Swelling Properties of the N-isopropylacrylamide/chitosan Semi-IPN and IPN Hydrogels. Journal of Applied Polymer Science, 82, 2487-2496. http://dx.doi.org/10.1002/app.2099

[87] Pan, J., Liao, H., Leygraf, C., Thierry, D. and Li, J. (1998) Variation of oxide films on titanium induced by osteoblast-like cell culture and the influence of an $\mathrm{H}_{2} \mathrm{O}_{2}$ pretreatment. Journal of Biomedical Materials Research, 40, 244-256.

http://dx.doi.org/10.1002/(SICI)1097-4636(199805)40:2< 244::AID-JBM9>3.0.CO;2-L

[88] Lum, H. and Roebuck, K.A. (2001) Oxidant stress and endothelial cell dysfunction. American Journal of Physiology. Cell Physiology, 280, 719-741.

[89] Selvam, S., Kundu, K., Templeman, K.L., Murthy, N. and Garcia, A.J. (2011) Minimally Invasive, longitudinal monitoring of biomaterial-associated inflammation by fluorescence imaging. Biomaterials, 32, 7785-7792. http://dx.doi.org/10.1016/j.biomaterials.2011.07.020

[90] Cheng, Y.-H., Yang, S.-H. and Lina, F.-H., (2011) Thermosensitive chitosan/gelatin/glycerol phosphate hydrogel as a controlled release system of ferulic acid for nucleus pulposus regeneration. Biomaterials, 32, 6953-6961.
[91] Kyle, J.L., Kimberly, B.B. and Melissa, J.M. (2010) Impact of degradable macromer content in a poly(ethylene glycol) hydrogel on neural cell metabolic activity, redox state, proliferation, and differentiation. Tissue Engineering Part A, 16, 1857-1866. http://dx.doi.org/10.1089/ten.tea.2009.0509

[92] Qi, H.M., Zhang, Q.B., Zhao, T.T., Hu, R.G., Zhang, K. and Li, Z.E. (2006) In Vitro antioxidant activity of acetylated and benzoylated derivatives of polysaccharide extracted from Ulva pertusa (Chlorophyta). Bioorganic \& Medicinal Chemistry Letters, 16, 2441-2445. http://dx.doi.org/10.1016/j.bmcl.2006.01.076

[93] Alves, A., Sousa, R.A. and Reis, R.L. (2013) Processing of degradable ulvan $3 \mathrm{D}$ porous structures for biomedical applications. Journal of Biomedical Materials Research, 101, 998-1006.

[94] Xue, C., Yu, G., Hirata, T., Terao, J. and Lin, H. (1998) Antioxidative activities of several marine polysaccharides evaluated in a phosphatidylcholine-liposomal suspension and organic solvents. Bioscience, Biotechnology and Biochemistry, 62, 206-209.

http://dx.doi.org/10.1271/bbb.62.206

[95] Chien, P.J., Sheu, F., Huang, W.T. and Su, M.S. (2007) Effect of molecular weight of chitosans on their antioxidative activities in apple juice. Food Chemistry, 102, 1192 1198. http://dx.doi.org/10.1016/j.foodchem.2006.07.007

[96] Mitha, M.K. and Jayabalan, M. (2009) Studies on biodegradable and crosslinkable poly(castor oil fumarate)/poly (propylene fumarate) composite adhesive as a potential injectable biomaterial. Journal of MaterialsScience: Materials in Medicine, 20, 203-211. http://dx.doi.org/10.1007/s10856-008-3518-y

[97] Finosh, G.T., Jayabalan M., Sankar, V. and Gopal, R.K. (2013) Growth and survival of cells in biosynthetic poly vinylalcohol-alginate IPN hydrogels for cardiac applications. Colloids and Surfaces B: Biointerfaces, 107, 137 145. http://dx.doi.org/10.1016/j.colsurfb.2013.01.069

[98] Xin, Y., Fong, Y., Wolf, G., Wolf, D. and C, W., (2001) Protective effect of XY99-5038 on hydrogen peroxide induced cell death in cultured retinal neurons. Life Sciences, 69, 289-299. http://dx.doi.org/10.1016/S0024-3205(01)01122-5

[99] Kurose, I., Higuchi, H., Miura, S., Saito, H., Watanabe, N., Hokari, R., Hirokawa, M., Takaishi, M., Zeki, S., Nakamura, T., Ebinuma, H., Kato, S. and Ishii, H. (1997) Oxidative stress-mediated apoptosis of hepatocytes exposed to acute ethanol intoxication. Hepatology, 25, 368-378. http://dx.doi.org/10.1002/hep.510250219

[100] Benhusein, G.M., Mutch, E., Aburawi, S. and Williams, F.M. (2010) Genotoxic effect induced by hydrogen peroxide in human hepatoma cells using comet assay. Libyan Journal of Medicine, 5, 4637-4643.

[101] Barzegar, A. and Moosavi-Movahedi, A.A. (2011) Intracellular ROS protection efficiency and free radical-scavenging activity of curcumin. PLOS ONE, 6, 26012-26019. http://dx.doi.org/10.1371/journal.pone.0026012

[102] Biswas, S.K., McClure, D., Jimenez, L.A., Megson, I.L. and Rahman, I. (2005) Curcumin induces glutathione biosynthesis and inhibits NF-kappaB activation and in- 
terleukin-8 release in alveolar epithelial cells: Mechanism of free radical scavenging activity. Antioxidants and Re- dox Signaling, 7, 32-41.

http://dx.doi.org/10.1089/ars.2005.7.32 